\title{
PERKEMBANGAN SOSIAL EMOSIONAL ANAK USIA 4-5 TAHUN: TINJAUAN PADA ASPEK KESADARAN DIRI ANAK
}

\author{
Aisyah Rodhwa Nisa ${ }^{1}$, Paras Patonah ${ }^{1}$, Yuli Prihatiningrum ${ }^{1}$, Rohita $^{1}$ \\ ${ }^{1}$ Program Studi Pendidikan Guru Pendidikan Anak Usia Dini, Fakultas Psikologi dan Pendidikan, \\ Universitas Al Azhar Indonesia, Jalan Sisingamangaraja Kebayoran baru, Jakarta Selatan, 12110 \\ Penulis untuk korespondensi/ E-mail: paraspatonah2@gmail.com
}

\begin{abstract}
Abstrak - Belajar dari rumah telah terjadi sejak awal tahun 2020 yang disebabkan karena adanya pandemi Covid-19. Pembelajaran yang dilakukan anak dari rumah bersifat dalam jaringan (daring) dimana dalam proses pembelajarannya anak-anak didampingi orangtua untuk memahami penjelasan yang disampaikan guru hingga mampu menyelesaikan tugas yang diberikan, termasuk memantau perkembangan sosial emosional anak, termasuk kesadaran diri anak. Tujuan penelitian ini adalah untuk mengetahui kesadaran diri (self awareness) anak usia 4-5 tahun selama belajar dari rumah. Metode penelitian yang digunakan adalah kualitatif dengan pendekatan deskriptif. Pengumpulan data dilakukan dengan membuat panduan wawancara dalam bentuk Google Form dimana tautannya disebarkan kepada responden melalui grup whatsapp. Subjek penelitian adalah orangtua murid dengan anak usia 4-5 tahun yang menyekolahkan anak-anaknya di TK di Al- Azhar 4 Depok. Analisis data menggunakan deskriptif kualitatif. Hasil penelitian menunjukkan bahwa selama pembelajaran daring anak memiliki perasaan bosan dan memiliki sikap malu ketika bertemu orang yang baru dikenal, baik orang dewasa maupun dengan teman sebaya. Namun anak masih dapat mengendalikan diri dengan menunjukkan ekspresi yang tepat atau tidak berlebihan, mau menolong tanpa diminta, serta mampu menyesuaikan diri dengan orang lain meskipun membutuhkan waktu yang lebih lama. Kesimpulan penelitian ini adalah kesadaran diri anak tetap terbentuk meskipun beberapa sikap yang ditunjukkan tidak sesuai dengan yang seharusnya dimiliki oleh anak usia 4-5 tahun sebagai salah satu dampak pembelajaran dari rumah namun sikap tersebut masih dalam batas yang wajar.
\end{abstract}

Kata Kunci : perkembangan sosial emosional, kesadaran diri, belajar dari rumah, anak usia 4-5 tahun

\begin{abstract}
Learning from home has been happening since the beginning of 2020 due to the Covid-19 pandemic. Learning that children do from home is online where in the learning process children are accompanied by parents to understand the explanations given by the teacher so that they are able to complete the tasks given, including monitoring children's social emotional development, including children's self-awareness. The purpose of this study was to determine the self-awareness of children aged 4-5 years while studying from home. The research method used is qualitative with a descriptive approach. Data collection was carried out by making an interview guide in the form of a Google Form where the link was distributed to respondents through the whatsapp group. The research subjects were parents of children aged 4-5 years who sent their children to kindergarten in Al-Azhar 4 Depok. Data analysis used descriptive qualitative. The results showed that during online learning, children felt bored and embarrassed when they met new people, both adults and peers. However, children are still able to control themselves by showing appropriate or not excessive expressions, willing to help without being asked, and able to adjust to others even though it takes longer. The conclusion of this study is that children's self-awareness is still formed even though some of the attitudes shown are not in accordance with what should be owned by children aged 4-5 years as one of the impacts of learning from home, but these attitudes are still within reasonable limits.
\end{abstract}

Keywords : emotional social development, self-awareness, learning from home, children aged 4-5 years 


\section{PENDAHULUAN}

$\mathrm{P}$ erkembangan sosial emosional penting dimiliki anak untuk dapat beradaptasi terhadap sesama dengan baik. Kemampuan sosial yang baik juga dapat membantu anak mengatasi berbagai permasalahan yang mungkin akan dialaminya dalam perjalanan kehidupannya kelak. Memiliki kemampuan sosial emosional yang baik memerlukan proses stimulasi yang sesuai. Sesuai dengan karakteristik anak dan sesuai dengan prinsip belajar anak usia dini.

Perkembangan sosial emosional dapat distimulasi melalui pembelajaran di sekolah dengan memperhatikan kurikulum yang berlaku, menggunakan berbagai metode serta berbagai media pembelajaran. Di dalam Standar Tingkat Pencapaian Perkembangan Anak, indikator perkembangan Sosial-emosional meliputi: (a) kesadaran diri, terdiri atas memperlihatkan kemampuan diri, mengenal perasaan sendiri dan mengendalikan diri, serta mampu menyesuaian diri dengan orang lain; (b) rasa tanggung jawab untuk diri dan orang lain, mencakup kemampuan mengetahui hak- haknya, mentaati aturan, mengatur diri sendiri, serta bertanggung jawab atas perilakunya untuk kebaikan sesama; (c) perilaku prososial, mencakup kemampuan bermain dengan teman sebaya, memahami perasaan, merespon, berbagi, serta menghargai hak dan pendapat orang lain; bersikap kooperatif, toleran, dan berperilaku sopan. menyesuaikan diri dan berinteraksi dengan lingkungannya, selain itu pentingnya keterampilan sosial juga mendukung anak untuk dapat berkomunikasi, menjalin hubungan dengan orang lain, menghargai diri sendiri dan orang lain serta memberi dan menerima kritik yang diberikan orang lain.

Kesadaran diri sebagai salah satu dari tiga indikator perkembangan sosial emosional sangat perlu dimiliki anak. Kesadaran Diri (Self Awareness) menurut Daniel Goleman (dalam Solomon) adalah kemampuan seseorang untuk mengetahui kekuatan, kelemahan, dorongan, nilai, dan dampaknya pada orang lain. Sementara Nafisa (2010) menyatakan bahwa kesadaran diri (self awareness) adalah keadaan dimana individu dapat memahami diri sendiri dengan tepat.

Seseorang yang memiliki kesadaran diri akan mampu menyikapi berbagai masalah dan keadaan yang dihadapinya dengan baik, karena orangtua tersebut mengetahui apa kekuatan dan kelemahan yang ia miliki. Orang tersebut juga akan bertindak hati-hati terhadap setiap keputusan yang diambil karena ia mengetahui dampak yang akan ditimbulkan dari keputusannya tersebut kepada oranglain. Pada akhirnya orang yang memiliki kesadaran diri adalah orang yang mampu mengambil keputusan untuk menyelesaikan masalah yang dihadapi tanpa merugikan dirinya dan juga orang lain. Di sisi lain, kesadaran diri (self awareness) yang baik akan dicapai bila individu dapat mengembangkan kemampuan untuk sadar diri, kemampuan untuk mengendalikan dorongan hati dan kemampuan untuk bersikap optimis (Goleman dalam Nafisa, 2010).

Stimulasi untuk meningkatkan kesadaran diri pada anak tentu banyak diberikan guru di sekolah. Hal ini merupakan kewajiban utama guru sekaligus pembuktian penguasaan berbagai kompetensi guru. Namun akan berbeda ceritanya jika anak berada di rumah. Selama pembelajaran daring, orangtua khususnya ibu terlibat lebih banyak dalam proses pendampingan saat anak-anaknya belajar. Orangtua tidak hanya perlu menyediakan waktu, untuk ikut mendengarkan pemaparan guru terkait materi dan tugas yang diberikan untuk dilakukan anak. Namun, di luar kegiatan pembelajaran daring, orantua juga harus mampu memberikan berbagai stimulus kepada anak agar potensi kesadaran dirinya dapat tetap berkembang optimal.

Tantangan yang dihadapi orangtua dalam pendampingan anak ketika belajar dari rumah tidak dapat dikatakan sedikit. Orangtua harus memiliki pengetahuan akan pendidikan anak, kemampuan membuat dan menyediakan media pembelajaran, kemampuan memilih metode, serta kemampuan menyediakan berbagai kegiatan yang menarik dan menyenangkan bagi anak, hingga anak mau terlibat aktif dan pada akhirnya dapat membantu meningkatkan berbagai potensi yang ada dalam diri anak, termasuk kemampuan kesadaran dirinya. Apabila hal tersebut tidak dapat terpenuhi maka bukan tidak mungkin perkembangan sosial emosional anak secara keseluruhan dapat terhambat

Adapun tujuan dari penelitian ini adalah untuk menggambarkan kemampuan kesadaran diri anak selama belajar dari rumah.

\section{METODE PENELITIAN}

Penelitian ini menggunakan pendekatan deskriptif kualitatif dengan teknik pengumpulan data menggunakan wawancara dalam bentuk google 
form. Pertanyaan yang diberikan merupakan pertanyaan tertutup, dimana responden hanya diperkenankan memilih jawaban yang telah tersedia pada setiap pertanyaan. Pertanyaan yang disusun pada kuesioner berisi topik capaian perkembangan yang terdiri aspek perkembangan sesuai ketetapan dalam Permendikbud No 137 tahun 2014 yaitu aspek social emosional. Adapun pertanyaan yang diajukan oleh orang tua secara lebih rinci, pertanyaan tersebutdapat dilihat di bawah ini:

1) Apakah anak di rumah saja selamapandemi?

2) Apakah anak anda bersekolah secara daring?

3) Bagaimana sikap anak selama sekolahdaring?

4) Bagaimana sikap anak bila diajakbertemu orang lain?

5) Apa reaksi anak bila bertemu teman daring/anak sebaya?

6) Apakah anak mengekspresikan perasaannya dengan tepat (tidak berlebihan)?

7) Apakah anak pernah menolong ataupun menawarkan bantuan untuk orang di rumah walaupun hanya untuk kegiatankecil saja?

8) Menurut anda, apakah sekolah daring tetap dapat mengembangkan sosialisasianak anda?

9) Apa alasan anda bila menjawab " dapat "?

10) Adakah perbedaan yang dilakukan anak saat berinteraksi dengan orang yang lebih tua dan dengan orang yang lebih muda?

Penelitian ini dimulai tanggal 23 April 2021 dengan cara menyebarkan kuesioner melalui Google Form kemudian tautannya disebarkan kepada para orang tua TK di Al-Azhar 4 Depok melalui grup WhatsApp kelas. Sebelum menyebarkan kuesioner, terlebih dahulu peneliti telah meminta izin kepada guru dan menjelaskan tujuan penelitian. Selain itu, peneliti juga telah menjelaskan bahwa dalam menjawab pertanyaan, guru diminta untuk melihat secara umum catatan penilaian hasil pencapaian aspek- aspek perkembangan anak selama pembelajaran tatap muka secara langsung di sekolah dan pencapaian aspek-aspek perkembangan anak selama pembelajaran daring dari rumah.

Hal ini dilakukan dengan tujuan untuk mengetahui apakah selama pembelajaran daring pencapaian perkembangan anak secara umum mengalami penurunan atau tidak. Data hasil kuesioner yang diperoleh selanjutnya dianalisis dengan menggunakan bantuan Microsoft Excel.
Adapun alur penelitian ini dapat dilihat pada gambar di bawah ini:

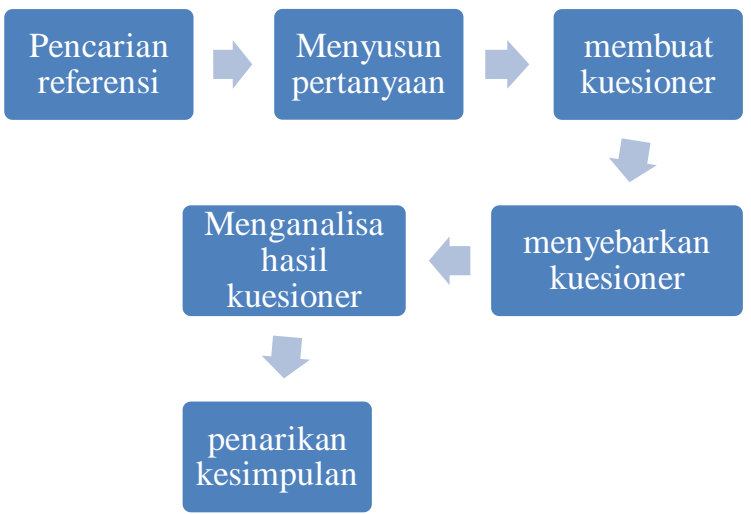

Gambar 1. alur penelitian

\section{HASIL DAN PEMBAHASAN}

Dari hasil penyebaran kuesioner yang dilakukan pada hari Sabtu, 24 April 2021 kepada 12 anak usia 4-5 tahun diperoleh informasi yang disajikan dalam bentuk grafik di bawah ini.

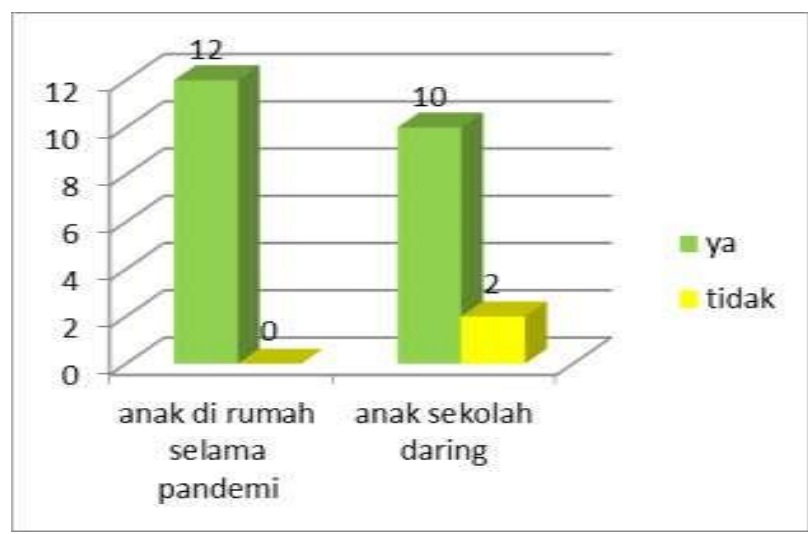

Gambar 2. keberadaan anak di rumah

Berdasarkan gambar 2 diketahui bahwa 100\% selama masa pandemi ini anak-anak hanya berada atau bermain di rumah saja. Dan hanya 2 anak saja dari 12 responden yang mengikuti kegiatan sekolah tatap muka. 


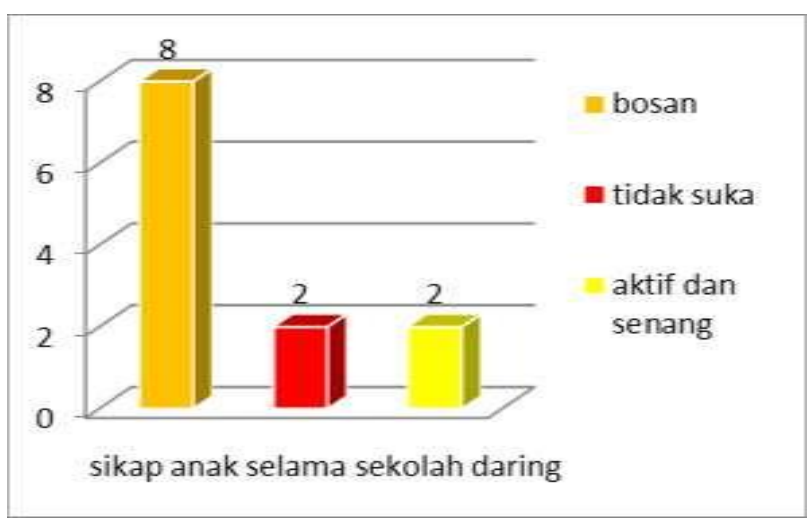

Gambar 3. sikap anak selama sekolah daring

Pada gambar 3 terlihat jelas bahwa anak-anak kebanyakan merasa cepat bosan bila mengikuti pembelajaran secara daring, hanya 2 anak yang mengatakan aktif dan senang mengikuti pembelajaran daring.

Tanpa disadari anak akan merasa bosan bila terus menerus berada di rumah, dan melakukan kegiatan atau aktifitas dirumah untuk mencegah penularan covid-19. Hal ini tentu berdampak pada sosial emosional anak, faktor yang mempengaruhi anak saat belajar di rumah adalah anak akan merasa cepat bosan karena pembelajaran dilakukan secara mandiri (Wiguna et al., 2020). Penerapan kebijakan belajar di rumah membuat sebagian siswa merasa cemasdan tertekan. Banyaknya tugas yang diberikan oleh guru membuat banyak siswa merasa stres dalam menjalani pembelajaran daring (Drane et al., 2020).

Rasa bosan merupakan situasi yang sering dialami semua orang terutama anak-anak dalam keadaan yang seperti ini. Kebosanan dapat timbul dikarenakan situasi lingkungan yang tidak menarik, cenderung monotong dan tidak termotivasi dan dari diri sendiri sudah bosan dengan suatu situasi. Hal ini menimbulkan kecemasan saat pembelajaran daring yang dilakukan selama pandemi covid 19, kecemasan tersebut munculnya rasa bosan saat belajar di rumah (Oktawirawan, 2020). Emosi yang timbul pada anak juga tergantung bagaimana orangtua atau orang disekitarnya mendukung bagaimana pembelajaran terjadi di dalam rumah, seperti yang dikatakan oleh (Drane et al., 2020). Emosional dukungan untuk pelajar dan keluarga mereka adalah kunci dan dukungan harus menjangkau dan proaktif untuk memastikan bahwa keluarga yang paling terpengaruh oleh situasi ini mengelola secara emosional, secara finansial dan logistik.
Di dalam hasil penelitian yang dilakukan Dayal \& Tiko (2020) dengan judul "When are we going to have the real school? A case study of early childhood education and care teachers' experiences surrounding education during the COVID-19 pandemic" menyatakan bahwa ditemukan berbagai derajat kesejahteraan emosional pra-taman kanak-kanak (di bawah lima) anak di AS, yang mengalami perasaan bosan atau bingung. Sebagai tambahan mengkhawatirkan $52 \%$ anak khawatir akan hal itu mereka tidak cukup belajar untuk mempersiapkan diri ketika sekolah dibuka, dengan persentase orang tua yang sama berbagi kekhawatiran yang sama. Dampak dari rasa bosan setiap anak berbeda tergantung bagaimana anak tersebut menyikapi dan menangani rasa bosan.

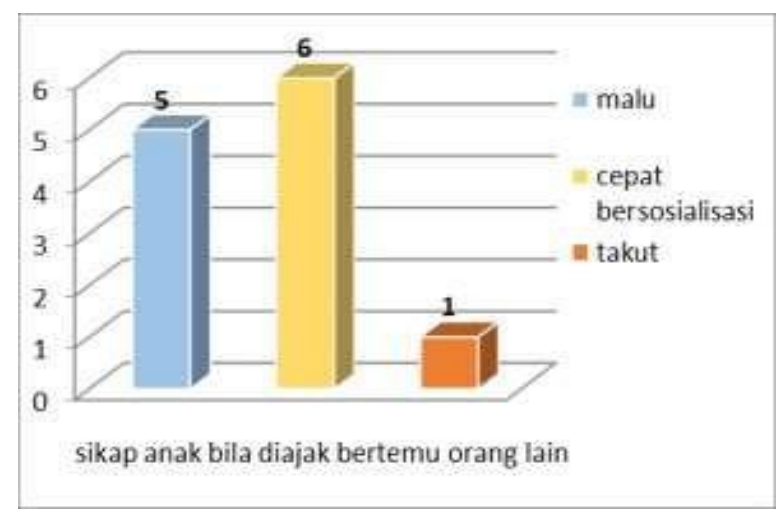

Gambar 4. sikap anak bertemu orang lain

Adapun sikap anak saat bertemu orang lain, berdasarkan gambar 4 terlihat bahwa 1 anak merasa takut dan spontan bersembunyi di belakang ibunya, sementara 5 anak merasa malu ketika peneliti menyapa. Namun 6 anak terlihat dengan cepat bersosialisasi.

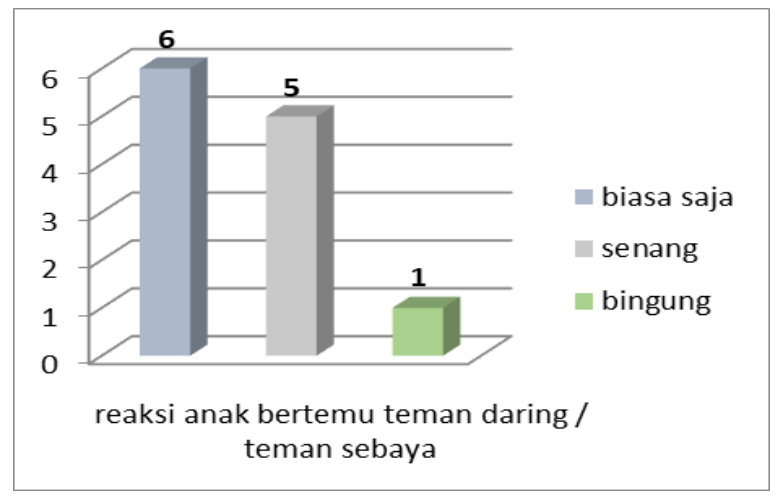

Gambar 5. reaksi anak bertemu teman

Lalu reaksi anak ketika bertemu teman sebayapun yang biasanya kebanyakan anak-anak akan 
langsung bermain bersama, tetapi dalam observasi seimbang antara anak yang senang bertemu dengan temannya dan sebagian lagi biasa saja, kemungkinan karena mereka hanya bertemu secara daring maka masih terasa asing satu dengan lainnya. Hanya 1 anak yang merasa bingung karena memang tidak pernah bertemu orang lain selain ayah, ibu dan neneknya selama pandemi.

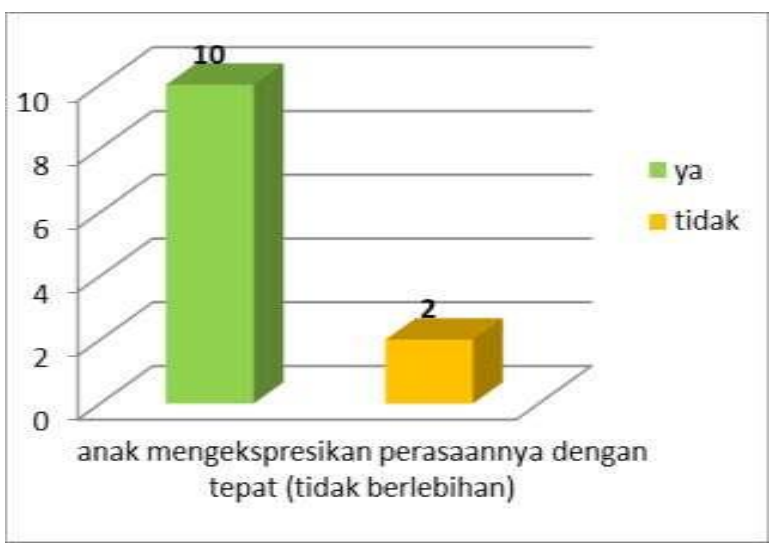

Gambar 6. kemampuan mengekspresikan perasaan

Terkait mengekspresikan emosi dengan wajar, berdasarkan gambar 6 terlihat hanya 2 anak yang mengekspresikannya belum tepat, dimana 1 anak saat daring akan merasa senang dan aman, tetapi ketika bertemu langsung dan diajak berbicara akan terlihat ragu dan lebih banyak bersembunyi di belakang bundanya. Sementara 1 anak lainnya, memang sulit beradaptasi di lingkungan baru dan mudah sekali berganti suasana hatinya.

Pembelajaran daring yang diakibatkan oleh adanya covid-19 tentu saja berpengaruh pada perilaku sosial emosional pada anak yaitu kurangnya bersosialisasi dengan teman disebabkan adanya belajar di rumah. Emosi anak yang terkadang merasa bosan, dan anak juga tercatat sebagian memiiki sifat yang pemalu atau pendiam. Fidiansjah (dalam Antara \& Prima, 2020) menyatakan bahwa dampak sosial emosional anak dari pembelajaran daring cukup mengkhawatirkan diantaranya adalah anak merasa bosan karena selalu berada di dalam rumah, serta anak merasa rindu ingin bertemu dengan teman-teman dan gurunya.

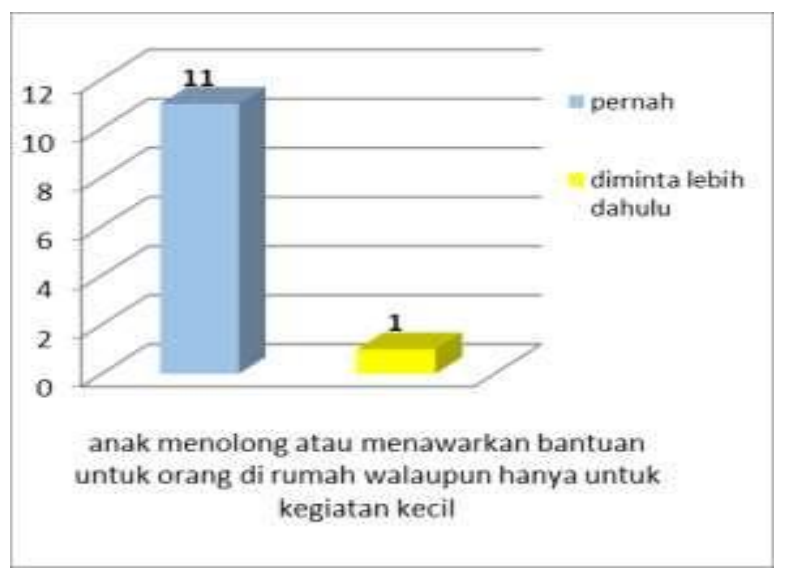

Gambar 7. sikap menolong anak

Sebagian besar dari anak-anak usia 4-5 tahun yang menjadi responden adalah anak yang suka membantu orang tuanya dan sangat senang bila dimintai bantuannya oleh orang tuanya. Pada gambar 7 terlihat bahwa dari 12 responden, 11 anak diantaranya mau menolong orang di rumah tanpa diminta. Menolong merupakan salah satu bentuk perilaku prososial yaitu perilaku sukarela yang dimaksudkan untuk meringankan kesulitan atau menguntungkan individu atau sekelompok individu lain biasanya dikategorikan pada sikap Helper (penolong) untuk mendapatkan pujian dari orang di sekitar yang kebanyakan terjadi di usia 6 tahun (Permatasari, Agustiani, Bachtiar, 2020).

Di dalam pembelajaran daring, mungkin anak tidak dapat melihat sikap menolong yang ditunjukkan guru ataupun teman-temannya. Namun dengan adanya pendampingan orangtua di dekat anak serta arahan guru untuk meminta bantuan orangtua jika anak mengalami kesulitan membuat anak mengetahui bagaimana mendapatkan bantuan sehingga pada akhirnya (mungkin) anak pun akan mengetahui bagaimana menolong oranglain dan kapan ia dapat melakukannya. Baik dengan diminta maupun tanpa diminta. Peningkatan kesadaran diri anak juga dapat dilakukan orangtua dengan menggunakan video pembelajaran, seperti video mitigasi bencana gunung meletus yang mengajarkan anak bagaimana tanggap terhadap bencana (Ningtyas \& Risina, 2018). 


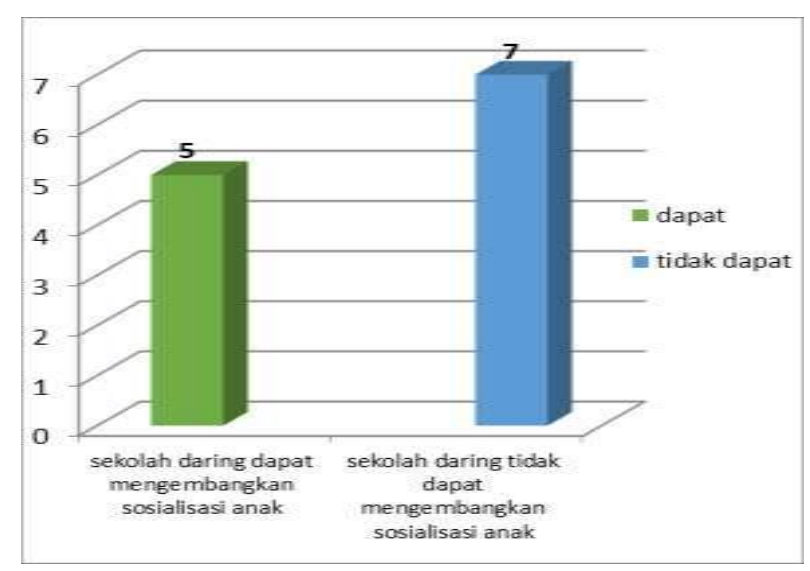

Gambar 8. pengembangan sosialisasi anak

Pada gambar 8 terlihat bahwa lebih dari separuh jumlah responden mengatakan bahwa sekolah daring tidak dapat mengembangkan sosialisasi anak, kebanyakan orang tua mengatakan bahwa sosialisasi bisa terjadi bila memiliki adik atau kakak di rumah. Sosialisasi yang dilakukan pada saat daring akan membingungkan anak karena tidak tahu seperti apa orang yang ada di layar. Untuk dapat bersosialisasi membutuhkan kontak fisik, dan sekolah daring tidak memfasilitasi kebutuhan tersebut.

Terkait reaksi yang ditunjukkan anak saat bersosialisasi dengan orang dewasa dan dengan teman sebaya diketahui bahwa kebanyakan bersikap sopan saat bersosialisasi dengan orang dewasa tetapi bila dengan teman sebaya masih suka berebut bahkan jadipendiam.

Proses bersosialisasi merupakan proses dimana seseorang belajar tingkah laku, kebiasaan serta pola-pola kebudayaan lainnya juga keterampilanketerampilan sosial seperti berbahasa, bergaul, berpakaian, cara makan dan sebagainya. Dalam proses pembelajaran di rumah, anak tidak bertemu teman sebayanya dan tidak bertemu dengan temantemannya di sekolah sehingga anak mengalami kurangnya bersosialisasi dengan orang sekitar atau teman sebayanya.

Perkembangan sosial merupakan perkembangan tingkah laku pada anak di mana anak diminta untuk menyesuaikan diri dengan aturan yang berlaku dalam lingkungan masyarakat. Dengankata lain, perkembangan sosial merupakan prosesbelajar anak dalam menyesuaikan diri dengan norma, moral dan tradisi dalam sebuah kelompok. perkembangan sosial emosi mengacu pada kemampuan anak untuk: memiliki pengetahuan dalam mengelola dan mengekspresikan emosi secara lengkap baik emosi positif maupun emosi negatif, mampu menjalin hubungan dengan anakanak lain dan orang dewasa disekitarnya, serta secara aktif mengeksplorasi lingkungan melalui belajar. Perkembangan sosial anak diperoleh dari kematangan dan kesempatan belajar dari berbagai respons lingkungan terhadap anak.

Perkembangan sosial yang optimal diperoleh dari respons sosial yang sehat dan kesempatan yang diberikan kepada anak untuk mengembangkan konsep diri yang positif. Melalui kegiatan bermain, anak dapat mengembangkan minat dan sikapnya terhadap orang lain. Dan sebaliknya aktivitas yang terlalu banyak didominasi oleh orang dewasa akan menghambat perkembangan sosial emosi anak.

Dari sisi emosional, kegiatan bermain dapat melatih anak dalam memahami perasaan teman lainnya. Konflik dalam interaksi keduanya akan membantu anak dalam memahami bahwa temannya memiliki cara pandang yang berbeda dari dirinya. Penurunan pencapaian perkembangan sosial emosional ini kemungkinan terjadi karena selama daring anak tidak dapat melakukan interaksi sosial dengan orang lain khususnya guru dan temantemannya (Wulandari \& Purwanta, 2020).

\section{SIMPULAN DAN SARAN}

Pembelajaran daring memberi dampak pada perkembangan sosial emosional anak usia dini, termasuk kemampuan kesadaran diri anak. Kondisi pandemi yang memunculkan diberlakukannya pembelajaran daring membuat sebagian anak memiliki rasa bosan, malu ketika bertemu dengan orang yang baru dikenal, serta biasa saja ketika bertemu teman sebaya. Namun meskipun demikian, anak masih dapat mengendalikan diri dengan menunjukkan ekspresi yang tepat atau tidak berlebihan ketika bertemu dengan orangorang yang baru dikenalnya baik bertemu secara daring maupun bertemu langsung. Anak juga mampu menyesuaikan diri dengan orang lain meskipun membutuhkan waktu yang lebih lama.

Keterlibatan orang tua dalam pendidikan anak dapat diwujudkan dalam berbagai bentuk aktifitas yang dilakukan oleh orang tua melalui kerjasama dengan guru baik di rumah atau di sekolah, guna memaksimalkan perkembangan dan pendidikan anak di sekolah demi keuntunganmereka, anak dan program sekolah. Hal tersebut sangat penting bagi kesinambungan antara pendidikan di rumah dan di 
sekolah. Pelaksanaan keterlibatan orang tua sendiri sangat memerlukankesadaran dan upaya dari orang tua terlebih lagi pihak sekolah, karena orang tua akan terlibat dengan aktif apabila sekolah berusaha untuk memberikan rasa nyaman bagi orang tua.

Adapun saran yang dapat diberikan adalah: pertama, pada pihak sekolah untuk dapat menunjukan sikap positif terhadap orang tua, sehingga orang tua merasa dihargai dan dibutuhkan di sekolah. Di samping itu, pihak sekolah juga hendaknya memiliki program kegiatan yang dapat meningkatkan keterlibatan orang tua dalam pendidikan anak mereka.

Kedua, bagi guru. Guru harus memiliki persiapan yang jelas mengenai materi yang akan dijadikan bahan pembelajaran kepada orang tua sehingga orang tua bisa menerapkan dan tidak dibingungkan dengan kegiatan bermain. Guru harus lebih memperhatikan kondisi dan situasi lingkungan keluarga peserta didik dan mengambil jalan tengah. Guru selalu mengedukasi orang tua tentang pembelajaran anak usia dini adalah belajar sambil bermain dan tetap selalu menerapkan prilakuprilaku yang berkaitan sosial emosional anak, maka guru harus aktif dalam berkomunikasi denganorang tua tentang pendampingan anak dalam setiap kegiatan.

Ketiga, bagi orang tua. Orang tua harus mau berperan aktif dan terbuka kepada guru mengenai perkembangan anak selama di rumah, sehingga guru bisa membantu memecahkan masalah yang terjadi. Orang tua diharapkan dapat selalu memberikan edukasi kepada anak tentang masa darurat virus Covid 19 yang sedang mewabah. Meyakinkan anak tentang alasan anak tidak diperkenankan berangkat kesekolah dan belajar di rumah namun tetap harus meningkatkan rasa sosial emosional anak kepada orang-orang di lingkungan sekitarnya. Orang tua juga harus tetap semangat sebagai guru di rumah agar anaksemakin semangat dalam melaksanakan kegiatan bermain di rumah dan menunjukkan sikap sosial emosional kepada orang lain agaranak dapat meniru dengan baik.

\section{DAFTAR PUSTAKA}

Dayal, H. C., \& Tiko, L. (2020). When are we going to have the real school? A case study of early childhood education and care teachers'experiences surrounding educationduring the COVID-19 pandemic. Australasian Journal of Early Childhood. https://doi.org/10.1177/183693 9120966085
Goleman, D. (2007). Emotional Intelligence (terjemahan). Jakarta: PT. Gramedia Pustaka Utama.

Nafisa, I. N. K. (2010). Efektivitas Motode Inabah Terhadap Self-Awareness Pada Pecandu Alkohol. Skripsi. Universitas Islam Negeri Sultan Syarif Kasim Riau.

Ningtyas, D.P., \& Risina, D.F. (2018). Peningkatan Self Awareness Anak Usia Dini Melalui Media Video Mitigasi Bencana Gunung Meletus. AlAthfal-Jurnal Pendidikan Anak. Vol. 4 No. 2. DOI: https://doi.org/10.14421/al-athfal.2018.4201

Peraturan Menteri Pendidikan dan Kebudayaan Republik Indonesia Nomor 137 Tahun 2014 tentang Kurikulum 2013 Pendidikan Anak Usia Dini. Jakarta.

Permatasari, P., Agustiani, H., \& Bachtiar, A. (2020). Benarkah anak prasekolah sudah mampu mengambil perspektif dalam perilaku prososial?. Jurnal Psikologi Sosial. Vol. 19 No. 1.

Solomon, D., \& Kalaiyarasan. (2016). Importance of Self Awareness in Adolescence - A Thematic Research Paper". IOSR Journal Of Humanities And Social Science (IOSR-JHSS). Vol. 21 No. 1 Ver. II.

Wulandari, H., \& Purwanta, E. (2021). Pencapaian Perkembangan Anak Usia Dini di TK selama Pembelajaran Daring saat Pandemi Covid-19. Jurnal Obsesi: Jurnal Pendidikan Anak Usia Dini. Vol. 5 No.1.

Wiguna, R., Sutisnawati, A., \& Lyesmaya, D. (2020). Analisis Proses Pembelajaran Siswa Berbasis Onine di Kelas Rendah Pada Masa Pandemic Covid-19. Jurnal Perseda. Vol. 3 No. 2.

Wulandari, H., \& Purwanta, E. (2020). Pencapaian Perkembangan Anak Usia Dini di Taman Kanak-kanak selama Pembelajaran Daring di Masa Pandemi Covid-19. Jurnal Obsesi : Jurnal Pendidikan Anak Usia Dini. Vol. 5 No. 1. https://doi.org/10.31004/obsesi.v5i1.626 